\title{
Virtual Politics, Real Guns: On Cloud Community, Violence, and Human Rights
}

\author{
Michael Blake
}

The creation of novel forms of information technology will put pressure on traditional forms of state sovereignty. The future, then, will be unlike the past. That much - to me, at least - seems beyond question. The more interesting subject, though, is whether we will be able to predict - from where and when we now are, with the technologies and histories we now inhabit what that future will look like. Liav Orgad, in his lead essay, offers us a compelling - and profoundly optimistic - vision of one possible future. In that future, our current world of sovereignty, in which human rights are nested in territorially limited sovereign states, is supplemented by a pluralistic and polycentric network of voluntary communities, mediated by information technology based upon self-sovereign forms of digital identity. The notion of global citizenship, in that world, might move from useful metaphor to lived reality; we could, at last, inhabit a world of our own choosing a world in which, as Francesca Strumia adds, we might join new worlds while never leaving home.

It is my lot, in these debates, to provide reasons to worry. I want to highlight and describe problems that stand in the way of moving from where we are now to where Orgad thinks we might soon be. I want to present these worries, not as permanent obstacles to the forms of life Orgad describes, but as problems we would have to solve before that world could be made real. The worries I describe stem from features of the state system that I think are poorly replicated in the world of cloud community and voluntary association; territorial states right now provide us with goods that cannot be provided by even the best systems of informational technology. To denigrate the importance of territorial states, in favour of these voluntaristic forms of association, might make things worse, rather than better.

I follow the lead of Rainer Bauböck, who notes the ways in which diversity of thought might be placed at risk in voluntary association, and Robert Post, who argues that the power of the state to punish cannot be replicated by a virtual and voluntary community. My own challenge is broader: the protection of human rights, I believe, can only be accomplished by means of 
violence and force, in both policing and in punishment - and this violence is in our world reserved (as a matter of right, if not reality) for use by states. Orgad's polycentric vision, in other words, must either acknowledge the continued relevance of the state system, and provide space for the preservation and maintenance of that system - or it must provide us with the resources to move beyond that system, by showing how violence might be rightly used by dispersed forms of intentional community. What I think cannot be doneor, at any rate, cannot be done easily - is to insist that informational technology has fundamentally transformed political reality, in the world in which we live. It might do so, of course; but I do not think it has done so yet - and there is a great deal of work to do, for philosophers and politicians alike, before that transformed world is open to us.

To see this, we might begin by looking at the notion of a failed state. What does such a state look like? A failed state, in the first instance, involves the absence of a political community sufficient to provide the means of survival; food, shelter, water, and so on. ${ }^{1}$ But the state rarely actually provides these goods itself; we do not expect the government to actually deliver us food and water, unless circumstances (or that government) have become very dire. What the state provides, instead, is coercion - coercion directed, in the first instance, at those people who would steal our food or water; at people who would break contracts with us as regards our labour; and so on. A state fails when it fails to provide the coercive means needed to preserve these liberties - or, on a broader vision of failure, when it sometimes provides the means of survival, and sometimes refrains from doing so. ${ }^{2}$

This is, to be sure, a minimal account of what a state must do; but it is already instructive. We should note, to begin with, that the use of coercion by the state is not here an optional part of its toolkit; coercion - which is to say, violence - is required of any state that is doing the job of the state. The second thing to note is that a great deal of political philosophy amounts to understanding what particular forms of violence might be justified specifically to the people gathered together within the coercive grasp of the state. ${ }^{3}$ Most of us, after all, regard the state as having a duty to do more than avoid failure; it has to be just in how it deploys these coercive powers that make it distinct. The state must, therefore, do justice to those people over whom it claims the power of rightful coercion. The final thing to note is that the state

\footnotetext{
Rotberg, R. I. (ed.) (2003), When States Fail: Causes and Consequences. Princeton: Princeton University Press.

2 Easterly, W. R. (2002), The Elusive Quest for Growth. Cambridge: MIT Press.

3 Rawls, J. (1989), Political Liberalism. New York: Columbia University Press.
} 
is supposed to be capable of offering, in any particular dispute about what justice demands, something very much like finality. Once the state has decided some matter of controversy, it is entitled to insist that its determination shall be non-optional for the political community over which it rules. ${ }^{4}$

Why, though, is any of this relevant to our discussion of blockchain and cloud community? It is relevant, I think, because of how our most important rights are linked to the state's use of violence. Our human rights are conceptually linked to violence; Hannah Arendt's often-cited 'right to have rights' demands the existence of an agency that will deploy force against those who would presume to deny or trespass on those rights. ${ }^{5}$ Our civil rights, too, are conceptually linked with violence; the reason I have the right to vote in the United States and not France, goes the argument, is that the law of the United States - and not France - gets to order me around, and to coerce me if I resist. This sort of coercion, though, is unavailable to even the most robust and well-developed forms of virtual association. We have, I think, very little sense of what it would be for them to have such coercive rights; and we have some good reason to worry that a world in which they had such rights might be a bad one indeed.

We can use these thoughts to develop some more specific worries about the examples used by Orgad in his essay. Take the notion of political participation in a virtual political community. Orgad suggests that such communities would form valuable spaces for political negotiation. I agree - so long as we are aware that such communities are political in only a secondary and derivative sense. The political community of the United States must engage in discourse whose aim is to determine what sorts of things the law of the United States shall do. This sort of political community is, I think, political in a primary sense; if the discourse were to stop, the justice of coercive law in the United States would necessarily cease. Other forms of political association, though, are political communities only in a secondary sense. If they were to cease their discussions, the world of discourse would likely be impoverished; but the justice of United States legal determinations, for example, would not be automatically placed into doubt. I think we might usefully call the United States' citizenry, and Amnesty International, political associations; certainly, they both seem associative, and they both seem political. But the two are distinct in how they relate to violence. The United States uses violence. Amnesty International offers criticism about how that violence is used. The latter sort of political community, in short, could not

4 Hart, H. L. A. (1961), The Concept of Law. Oxford: Clarendon Press.

5 Arendt, H. (1994 [1951]), The Origins of Totalitarianism. New York: Harcourt. 
even in principle replace the former. It might make the political deliberations in the former more robust, and more likely to do justice. (Certainly, a world without Amnesty International would likely have worse states in it than our own world.) But the virtual political community cannot do the job of the state's political community. The fact that we can use the phrasing of political community in both contexts should not obscure the vast differences between the two sorts of human association.

I would suggest that something similar might be felt about blockchain cryptography, which produces self-sovereign forms of identification. These forms of identification are sovereign, in that they are initiated with and controllable by the individual; but the individual has no greater sovereignty, in the sense used in international law, after her digital ID than before it. What the digital ID would provide, after all, is information. Information, we say, is power; but so too is, well, power, in the ordinary sense in which states use military might to preserve their sovereignty. What is required for rights to be protected, following on our discussion above, is a set of powerful agents willing to deploy violence against those who would do violence against us. The digital ID might be used to frustrate some forms of malignant state action - and, of course, allow others. What it cannot do is provide the violence that is conceptually linked with our human rights. If one is not possessed of a state willing and able to use violence on one's behalf prior to the digital ID, one is not provided with one once that ID is created.

I suspect similar things might be said of the Estonian experiment. People have long been able to engage in contracts with foreign companies, and foreign states, for particular ends; we engage in international trade, we accept particular patterns of dispute resolution, we agree to the terms limiting our rights as foreign visitors, and so on. It is not clear what, in particular, changes with the creation of a computer system capable of centralising and administering our dealings with a foreign state. I am open to being convinced otherwise, but my initial reaction is that registering as an e-Estonian no more makes me Estonian than changing planes at Heathrow makes me British. The Estonian state has obligations to its own citizens that it does not - or, at least, does not yet - have to me. So long as the e-Estonian system leaves that fact fundamentally unchanged, it is not clear to me that the virtual association it creates is even a pale shadow of a genuine political community.

All this, I should repeat, is intended not to defeat Orgad's vision, but to outline what I take to be significant worries about how we might make that vision real. Orgad does not want these voluntary forms of transnational institution to take the place of states, but insists upon their validity and 
power as 'state-like entities.' It is this latter point with which I take issue. If these institutions are to become genuinely state-like, they must have some part in doing what it is that states do; and we must understand how they could do that sort of thing, and how we could move from where we are to where we might be. If, in contrast, these institutions are merely places for debate and for the creation of solidarity, then we have had them for a very long time indeed; Amnesty International has been helped by the digital revolution, but had a life prior to that revolution. It is not clear what these tools provide us with except for scale and ease. Either way, I suggest, we have some work to do. Orgad is, I believe, well-positioned to help with this work; as I noted at the beginning, his vision is profoundly hopeful, while my own is not, and I genuinely hope I can be proven wrong.

Open Access This chapter is licensed under the terms of the Creative Commons Attribution 4.0 International License (http://creativecommons.org/licenses/by/4.0/), which permits use, sharing, adaptation, distribution and reproduction in any medium or format, as long as you give appropriate credit to the original author(s) and the source, provide a link to the Creative Commons license and indicate if changes were made.

The images or other third party material in this chapter are included in the chapter's Creative Commons license, unless indicated otherwise in a credit line to the material. If material is not included in the chapter's Creative Commons license and your intended use is not permitted by statutory regulation or exceeds the permitted use, you will need to obtain permission directly from the copyright holder.

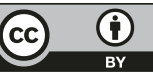

